\title{
Mumpreneurship for urban development
}

\author{
Nazeeh Elsebaie ${ }^{1, *}$, Elena Ganebnykh ${ }^{1}$, and Mikhail Lunyakov ${ }^{2}$ \\ ${ }^{1}$ Vyatka State University, Moskovskaya street, 36, Kirov, 610000, Russia \\ ${ }^{2}$ Moscow State University of Civil Engineering, 26, Yaroslavskoe Sh., Moscow, 129337 Russia
}

\begin{abstract}
This article examines the experiences of women entrepreneurs who started their business in the maternity or childcare leave period. The findings significantly differ from those case studies reported in the literature. The examined case highlights the financial reason that contradicts earlier publications regarding European women who 'want to be a good mom, but not just a housewife'. Furthermore, the study revealed the lack of knowledge among mumpreneurs in the field of law and taxation. Therefore, they mostly operate without official registration and pay no taxes. However, the data from this study revealed certain latent entrepreneurial potential that can be developed and may influence socioeconomic development of the community.
\end{abstract}

\section{Introduction}

The last two decades of entrepreneurship history point to the increasing role of women in business. Today women owned business is one of the most rapidly developing kinds of entrepreneurship [1]. According to Global Entrepreneurship Monitor, the number of women-entrepreneurs in countries with factor-driven economies is almost equal to the number of men-entrepreneurs, especially at the early-stage of entrepreneurial activity (ratio 0.86). This ratio goes down to 0.73 in efficiency-driven economies and to 0.59 in innovation-driven economies [2]. At the same time, gender, age, and motivation are the key factors of early-stage entrepreneurship.

Most entrepreneurs around the world are opportunity-motivated. However, the phenomenon of mumpreneurship has another basis and another reason. The 'mumpreneur' term has been defined relatively recently. This neologism is based on a combination of two terms 'mum' ('mom') and 'entrepreneur', and thus combines both characteristics. Oxford Dictionary defines a mumpreneur as "a woman who sets up and runs her own business in addition to caring for her young child or children [3]." A more profound description of this term is given by Ekinsmyth: 'an individual who discovers and exploits new business opportunities within a social and geographical context and who seeks to integrate the demands of motherhood and business ownership [4]. This emphasizes that mumpreneurship phenomenon has a deeper meaning than just "business beside a childcare."

A large number of contemporary research papers analyze the influence of different factors on the decision to become an entrepreneur [5-9]. Significant attention is paid to mumpreneurship issues [10-16], but this relatively new concept requires theoretical

* Corresponding author: nsebaie@outlook.com 
justification based on empirical evidence. A large number of research papers describe the experience of mumpreneurs in the UK [17-19]. Nevertheless, some European case studies from France [20], Germany [21, Sweden [22], Malta and Finland [23], as well as Australian experience [24], and even cases from Botswana [25] encourage the formation of comparative theoretical base. Unfortunately, there is a total lack of evidence from Russia, while it can be indicative for understanding the alternative experience of countries in this region. Common social background of post-Soviet countries also has significant importance since it shapes the environment where mumpreneurship emerges.

Patterson and Mavin [26] distinguish push and pull factors that influence the decision of young mums to start their own businesses. The evidence about mumpreneurship described in the earlier research highlights the dominance of pull factors in European countries and push factors in the countries with factor-driven economies. Pull factors are related to advantages of self-employment, such as flexible working hours. Push factors are usually related to a forced search for employment, which is particularly limited in the period of women's maternity or childcare leave.

\subsection{Depressed areas}

Russia stands an extremely huge territory. One feature of Russia's economy is a large gap in economic development of its regions. According to statistics, the average income of residents of the 'richest' area, Yamalo-Nenets Autonomous County, is 160 times more than the average income in the 'poorest' area, Pskov region [27]. For our purpose, all Russian regions can be divided into economically successful, depressed, and crisis areas. Successful and crisis regions, as the opposite poles, demonstrate strong and weak economies. Depressed areas are of particular interest, because they can potentially increase their wealth, though at present for various reasons they are in economic downturn. These regions have outdated technologies and low market adaptation [28], which leads to low standards of living and a high level of unemployment.

Initially, the objective of our research was to identify the needs, reasons and grounds for women-entrepreneurs to start and run their own business in a depressed area of Russia during the period of their maternity or childcare leave. The findings of our research have considerable practical implications due to the need to raise the employment rate in such areas. However, during the initial stage of the research it turned out that mumpreneurship has a good potential to be transformed into a full-fledged business in the future. Selfemployment always positively influences economic development: infrastructure develops, new work places emerge, budget replenishes by taxes and so on. In fact, most mumpreneurs are not taxpayers due to the unofficial character of their business. This reduces overall benefits of entrepreneurial activity for the economy of the region. Consequently, the objectives of the study were further developed. It was considered necessary to reveal women's development plans and factors that can contribute to this. This process can be seen as one of the ways of developing entrepreneurship in depressed areas.

This paper examines the experience of a particular subset of women entrepreneurs who run their business in one of the depressed areas of Russia, Kirov region. Since it is impossible to calculate the exact number of mumpreneurs, no sample can be considered representative. They will anyway have the character of a case study. Most of the previous work in this field has been done in other countries in the same way. Qualitative methods are to be used for the deeper understanding of mumpreneurs' experience. 


\section{Materials and methods}

The major purpose of the research was to describe mumpreneurship, its kinds and factors influencing its development in Kirov region. Literature review indicated that actually mumpreneurship-related topics have not been given specific attention in Russia. This highlights the necessity of primarily descriptive studies of this specific emerging form of entrepreneurship. So, with this in mind, we applied illustrative case study method for the depressed area (Kirov region). Case study results are not supposed to be generalized, but they describe a particular situation in a particular area.

\subsection{Sample}

The study is based on interviews with nine women and was conducted in 2018. Since the Kirov region could be referred to depressed areas of Russia, the first criterion for the sample was the respondent's permanent residence on its territory. The second criterion was the start of business in the period of maternity or childcare leave. Representative sample of the total set might have given higher quality information. However, it is impossible to determine the total quantity of mumpreneurs since they mainly perform their business 'in shadow.' The social network VK (http://vk.com - popular Russian social network), as well as personal contacts, was utilized in order to select the potential respondents. Primarily we selected 28 women who met the requirements, but only one third of them agreed to give an interview. As a result, a total of 9 women who met the requirements were selected for this study. Six of the nine women were on childcare leave in the period of the interview, and three women were already out of their maternity leave and continued further development of their business. All respondents were aged between 27 and 38. Table 1 reflects the summary of the interviewees.

Table 1. Sample.

\begin{tabular}{|c|l|l|l|c|c|c|c|}
\hline No & Name & \multicolumn{1}{|c|}{ Business } & Children & $\begin{array}{c}\text { Married } / \\
\text { partner }\end{array}$ & $\begin{array}{c}\text { Officially } \\
\text { registere } \\
\text { d } \\
\text { business }\end{array}$ & $\begin{array}{c}\text { Hom } \\
\text { e } \\
\text { based }\end{array}$ & $\begin{array}{c}\text { Employed } \\
\text { staff }\end{array}$ \\
\hline 1 & Maria & Hairdresser's parlor & $2(5,1 \mathrm{yr})$ & Yes & No & Yes & - \\
\hline 2 & Daria & Nail design parlor & $1(1 \mathrm{yr})$ & No & No & Yes & - \\
\hline 3 & Anna & Internet-shop (baby clothes $)$ & $1(4 \mathrm{yrs})$ & Yes & No & Yes & - \\
\hline 4 & Ksenia & Beauty parlor & $1(2 \mathrm{yrs})$ & Yes & No & Yes & - \\
\hline 5 & Ekaterina & Text translations & $2(7,1 \mathrm{yr})$ & Yes & No & Yes & - \\
\hline 6 & Irina & Desktop publishing & $1(2 \mathrm{yrs})$ & Yes & No & Yes & - \\
\hline 7 & Olga & Distribution of cosmetics & $1(1 \mathrm{yr})$ & No & No & Yes & - \\
\hline 8 & Yulia & Tailoring studio & $1(8 \mathrm{yrs})$ & No & Yes & No & 2 \\
\hline 9 & Nadia & Beauty services, massage & $2(3,1 \mathrm{yr})$ & Yes & No & Yes & - \\
\hline
\end{tabular}

\subsection{Data collection}

According to Larty and Hamilton, the interview should enable interviewees to perform personal narratives of their experience [29]. So we conducted an informal face-to-face interview which was semi-structured and specially designed to obtain in-depth information. In fact, only the skeleton plan of the interview with several open-ended questions had been predefined. The interview was conducted at respondents' own homes or in a small coffee shop in a relaxed friendly atmosphere, and it lasted 1 to 2 hours. This duration enables the interviewer to gain the trust of the respondent and to engage them in a frank conversation $[30]$. 
The first part of the interview was devoted to the respondent's social background and the description of the environment where a woman lives. Since the interviewer did not establish any polling frames, the description of different motives that influenced the decision to start their own business was encouraged. In the second part of the interview, the women described the features of their business. Considerable attention was given to the experience that they had obtained during their mumpreneurship, as well as to the lack of knowledge and support they may have felt. Finally, in the third part of the interview it was necessary to learn mumpreneurs' views on the development of their business and their further plans. Besides, the interviewer attempted at finding out the factors that had affected or might affect the continuation of self-employment of these women. All the interviews were digitally recorded and later transcribed on paper in order to address the issues of credibility and confirmation. In all interviews women's consent was obtained.

\subsection{Data analysis}

During the study the questionnaire was changed and modified several times due to the fact that the open-ended semi-structured interview raised unexpected topics of social prestige and entrepreneurial networking. Comparison of the data collected from such interviews traditionally presents a significant difficulty. We utilized the content analysis method using a posteriori approach since it set up categories that are meaningful in terms of the empirical material gathered during the course of the study [31-32]. As the sample size was small, we tried to single out common parameters that were characteristic of all or at least of the majority of the interviews.

\section{Results}

The major purpose of the research was to describe mumpreneurship in a depressed area, as well as to distinguish factors influencing its development. In our view, the results of the research are of high importance, because the case study was performed in a depressed area, as it radically differs from previous studies (Duberley, J. and Carrigan, M., 2012). In contrast to earlier findings that focused on a combination of business and motherhood, our study is aimed at finding recipes for legalization of mumpreneurial shadow business and development with involvement of employees. This goal is determined by the demand for workplaces in depressed areas. Case method was utilized for a detailed review of the current situation. It was based on the interview with nine women-entrepreneurs and its subsequent interpretation. The findings significantly differ from those case studies reported in the literature.

\subsection{Description}

Table 1 reflects the summary of the interviewees. During the interview, we talked to nine women, two-thirds of whom are currently on maternity leave. Almost half of them are engaged in various types of beauty services, two of them work on PC remotely, and one woman is engaged in online selling of baby clothes. Eight out of nine respondents work at home without assistants, and their business is not registered officially. The only respondent who differs from the majority is Yulia, the owner of a tailoring studio. Her studio is registered and officially employs Yulia and two more people. Eight out of nine respondents have children aged 1 to 4, which means that mums are on childcare leave right now.

The majority of the women ( 6 out of 9) are married, and they are not the only breadwinners in their families. At the same time, four of them feel that the level of their 
business income is essential for the family budget. Three respondents are not married, and their business income is, in fact, their only financial source apart from the allowance for child care. In Russia, the size of allowance for women on childcare leave comprises $40 \%$ of the average earnings before the maternity leave with a minimum guaranteed amount of 2700 roubles per month for the first child $(\approx$ USD40) and 5400 roubles per month for the second and subsequent children $(\approx \mathrm{USD} 80)$. Given this fact, it is obvious that a single mother with no significant savings has to look for opportunities to earn additional income.

\subsection{Motivation}

The expected motive of women to launch their businesses was the matter of finance. However, in an attempt to find out what led each one to a particular type of activity, we found that five women decided to use an opportunity and learn new skills in the industry which they had been interested in for a long time. Noteworthy, three out of five respondents who are occupied in the beauty industry learned their skills during their maternity leave.

Anna started online sales of baby clothes when she discovered a large amount of her own daughter's dresses that she does not wear any longer.

'Children grow up so fast! So much clothing was bought and gifted to my child even before her birth that we did not have a chance to put on every single item at least once! When my friend got pregnant, I prepared a suitcase of clothes for her baby. But it became clear that our pink dresses will not suit when we found out that she was expecting a babyboy. I started selling in Avito (popular Russian web-portal where people sell used valuables), and women were coming and taking piles of clothes. Then I decided to sell baby clothes online. Initially I continued to sell on the same web-site, and then I made my own page at VK'.

The rest of the women continued to do what they had been doing before pregnancy, they just tried to set the remote mode of their job. This group of the respondents has different motives.

Ekaterina and Irina work from home on the computer. Ekaterina is a professional interpreter. She used to work in a translation agency before the maternity leave. This work does not take a lot of time and brings a steady income. In addition, there is no need to visit the office. Ekaterina gained the experience of remote work during her leave for the first child and she decided to repeat it. Now Ekaterina provides outsourcing translation services to several agencies. Irina makes desktop publishing for the magazine. She intends to demonstrate a highly responsible approach to her work, so she cannot let the company down. In addition, this way she can always be in the thick of things and does not feel isolated from the familiar social environment. At the same time, Irina offers proof-reading of scientific texts to third-party companies and private customers.

Yulia is a professional tailor and she has a vocational education. She was an employee in the tailor studio before the maternity leave and she had more than two dozens of regular customers. During the maternity leave, she continued to serve her customers at home. Her child started to attend kindergarten when he was 3 years old, and Yulia got more free time. Now she owns a studio, pays taxes and provides two workplaces.

In summary, the key motive to launch a particular kind of business can be identified with each woman (see table 2). 
Table 2. Reasons.

\begin{tabular}{|c|l|l|l|}
\hline No & Name & \multicolumn{1}{|c|}{ Business } & \multicolumn{1}{c|}{ Main reason } \\
\hline 1 & Maria & Hairdresser's parlor & $\begin{array}{l}\text { She had been interested in the beauty industry for a } \\
\text { long time, and she decided to learn new skills }\end{array}$ \\
\hline 2 & Daria & Nail design parlor & $\begin{array}{l}\text { She had been interested in the beauty industry for a } \\
\text { long time, and she decided to learn new skills. }\end{array}$ \\
\hline 3 & Anna & $\begin{array}{l}\text { Internet-shop (baby } \\
\text { clothes) }\end{array}$ & $\begin{array}{l}\text { It was necessary to sell her own stocks of baby } \\
\text { clothes. }\end{array}$ \\
\hline 4 & Ksenia & Beauty parlor & $\begin{array}{l}\text { She had been interested in the beauty industry for a } \\
\text { long time, and she decided to learn new skills. }\end{array}$ \\
\hline 5 & Ekaterina & Text translations & $\begin{array}{l}\text { She already has skills to do this job. There is no need } \\
\text { to visit the office. The work provides a flexible } \\
\text { schedule. }\end{array}$ \\
\hline 6 & Irina & Desktop publishing & $\begin{array}{l}\text { She wants to keep abreast of developments and remain } \\
\text { within her familiar social group. }\end{array}$ \\
\hline 7 & Olga & $\begin{array}{l}\text { Distribution of } \\
\text { cosmetics }\end{array}$ & $\begin{array}{l}\text { She has been in this business for a long time, regular } \\
\text { customers continue to purchase, so she need not make } \\
\text { any special efforts. }\end{array}$ \\
\hline 8 & Yulia & Tailoring studio & $\begin{array}{l}\text { She wanted to keep regular customers in order to stay } \\
\text { in business after the maternity leave. }\end{array}$ \\
\hline 9 & Nadia & $\begin{array}{l}\text { Beauty services, } \\
\text { massage }\end{array}$ & $\begin{array}{l}\text { She decided to learn baby massage technique for her } \\
\text { own children. }\end{array}$ \\
\hline
\end{tabular}

Describing the different experiences of women, however, we cannot say that financial motive is insignificant. Each of them agreed that this reason exists: in some cases, it is more edgy, in some less. In response to the question 'Would you continue to do your business if it still brings pleasure / moral satisfaction, but has ceased to be profitable?' $100 \%$ of those surveyed answered: 'Definitely not.' Thus, the financial component is also an important factor.

It is noteworthy that women with higher education have continued to work in their field trying to adjust the mode of employment and to create a more flexible schedule. Women with no education or with vocational education managed to learn new skills and they dramatically changed the type of activity.

\subsection{Business legalization}

Eight out of nine interviewed women perform their business informally. They are not registered with the tax authorities as entrepreneurs and do not establish a company. Accordingly, there are no tax revenues from their activities. Tax revenues are an important financial component of any regional budget, but it plays a vital role in depressed areas. Therefore, understanding the reasons of entrepreneurial behaviour can help build policies encouraging entrepreneurs to get out of the shadows.

The research revealed two root causes of reluctance to register respondents' own business. Firstly, as was anticipated, it is the desire to avoid tax payments. Secondly, it is ignorance of or delusion regarding the matters of registration.

Comparing the amount of their income from business activities and the size of obligatory payments to the budget, 6 women stated that they would be forced to give away about half of the money earned. One respondent pointed out that the payment would be about $80 \%$ of her revenues. One woman said that she had never considered these payments.

'The State should support me during my maternity leave. Everyone knows the amount of allowance. They should say 'thanks' to mums who manage to earn their living at this 
time. If they said: 'Register your business, but do not pay taxes until the child turns 3 years old', I would register. Why not?"

Despite these results, it can be concluded that the large majority of women considered the possibility of business legalization, because they quite clearly handled financial information regarding this issue. This fact can be considered positive. It highlights the availability of opportunities to transfer such entrepreneurs into the legal zone.

Also, the survey showed that two thirds of women (5 out of 8 ), who operate without proper registration, do not have information about the risks of punishment for their work. Three women know that they may be penalized, but consider this possibility negligible. Not being a supporter of tougher penalties, authors suggest the necessity to develop policies that promote the transition to official business.

\subsection{Future plans}

An important objective of the study was to find development opportunities for mumpreneurship with further involvement of employees. It is important for a depressed area as it creates new workplaces. During the interview the respondents were asked about their future plans.

Yulia, the owner of the tailoring studio, is planning to develop her business by entering into large-scale contracts for sewing coveralls. If she gets a large order, she will hire three more employees from among vocational school graduates. Usually the profit from such orders is not large, and graduates with no work experience do not require high wages.

Two women who work in the beauty industry are planning to continue what they are doing at the moment. In fact, one of them is planning to open her own manicure parlor or to lease a workplace in a studio. Both respondents stated that they want to improve their skills and participate in competitions and fashion shows. In response to the question of what could motivate them to expand their business and hire employees, both noted inexpensive rent for the parlor.

Anna, who is engaged in online sales, believes that this sector will develop in future, so she is on the right track. She is planning to widen the range of products for other age groups and improve her website. At the same time, Anna admits the probability of taking on an employee responsible for the web-site maintenance. However, she would like to see a partner, not an employee.

Katerina and Irina, who work remotely on home computers, are planning to return to their companies as hired employees. At the same time, Irina enjoys photography and took an interest in advertising design during her maternity leave. She would not give up the idea of developing these skills and working with customers directly. Irina believes that she needs to create a brand for her own studio to attract customers. Therefore, the official registration will be vital, but salaried employees are not included in her plans due to the small amount of work.

The respondent, who is engaged in distribution of cosmetics, is not planning to change anything, because the network marketing scheme, in fact, does not imply employment. Earlier, Olga already considered a cosmetics store business-plan, but the result was unprofitable. Two respondents have not thought about future plans since they are at the beginning of their maternity leave. They started their businesses a couple of months ago, and have not yet understood their own intentions. Nevertheless, they clearly do not have prejudice against the expansion of the business if it is going to be successful.

Thus, we can say that the majority of women consider the current business as a temporary and to some degree unexpected thing, which challenges them to change something in their lives. All the women are optimistic and are full of plans for the future. This result has further strengthened our confidence in the belief that very little 
governmental impulse is necessary for the further development of this specific type of business. These findings underline the importance of understanding causes of behavior for the formation of correct control action. Our study provides further evidence for mumpreneurship in line with earlier findings. Even though our results differ from published studies, they extend knowledge in this area.

\section{Discussion}

Any entrepreneur passes certain stages in the formation of business: discovering opportunities, concept development, resourcing, operating an organization and harvesting. Mumpreneurship essentially includes at least first four stages. It should be understood that the first stage (discovering opportunities) is much more than just a search for a business idea. A business idea is a concept for a new product or service under-represented in the market. In contrast, the opportunity is a business idea, demanded by the market, so it can form the basis for commercial profit. Commercial profit largely depends on the entrepreneur's costs of business operation. Aiming at developing mumpreneurship in a particular region it is possible to reduce these costs by minimizing tax payments. This important factor could potentially push more women on the maternity or childcare leave to do business.

The second important factor in mumpreneurship development is involvement of mumpreneurs in the fifth stage, i.e. it is necessary to encourage them to work for business growth. There are many universal ways to promote small business: lower interest rates, preferential taxation, subsidies for lease and assistance in promotion of products in external markets, etc. But the complexity of mumpreneurship arises from the fact that the vast majority of women operate in the market informally. Therefore, the initial step should be the intensive call for them to go "out of the shadows." The findings showed that tax holidays would be an effective tool. Probably, this measure would be more effective combined with an alternative of the patent taxation system, when a person buys rights to perform business with no registration as an entrepreneur or a legal entity.

The contradictory nature of the essence of mumpreneurship, when women are forced to spend less time at work than in regular periods of their life, prevents the establishment of restraints and incentives for their business development. Studies of Du Reitz and Henrekson [31] showed that women choose to limit the development of their business to maintain a balance between the time spent at work and the childcare. It would be logical to assume that the evolution curve of the mumpreneur's business will differ from the standard one and will have a sloping growth section. Major efforts to involve mumpreneurs in business development should be made at the time when the child reaches the age of 3-4 years. This is due to the peculiarities of the Russian preschool education system. At this age Russian children start attending a kindergarten. As a result, women have more time and can concentrate more efforts on their business.

Often, women do not perceive their business as a business. For them it is just a hobby that provides additional income. Self-identification of a woman as entrepreneur seems meaningful. Self-identity as a business owner forces to start taking care of this business. When a woman realizes that she has grown from a mumpreneurs to a business-lady, it can be assumed that she is involved in the fifth stage - the development of business.

\section{Conclusion}

Comparing mumpreneurship in depressed regions of Russia with cases from Western countries, we found that the main difference is its root cause. The examined case highlights 
the financial reason contrary to the earlier publications regarding European women who 'want to be a good mom, but not just a housewife'. In our opinion, reasons for mumpreneurship are crucial for understanding the development tools for this type of business.

In general, any entrepreneur enters into a conflict of interests with the state, since his goal is to increase profits, and the goal of the state is to increase budget revenues. Thus, there are two bidders for the limited financial resource. Therefore, the effectiveness of the state policy regarding entrepreneurs is determined by the balance of interests, where each party receives the best possible result. Obviously, the standard regulations are not suitable for mumpreneurship. Since the financial issue here is of prime consideration, the equilibrium point must be shifted, leaving the mumpreneur more funds available. The more finance remains in the mumpreneur's hands, the greater encouragement they get to develop their businesses.

Furthermore, the study revealed the lack of knowledge among mumpreneurs in the field of law and taxation. Current legislation does not take into account the peculiarities of mumpreneurship, so it does not fully meet the needs of this form of entrepreneurship. However, even the information about the current law regulation of entrepreneurship should be more accessible to this group of business people. Also, multiplication of successful experience of other mumpreneurs may be effective. To do this, it is necessary to study the experience of other countries and regions and to form a program fostering interest to mumpreneurial activities.

Entrepreneurship is essential for the economic and social development of the community. Taking into consideration the positive impact of entrepreneurship, many states implement aggressive strategies aimed at cultivating and nurturing entrepreneurs. In order to effectively develop policies that will foster entrepreneurship, first of all it is necessary to understand its forms and patterns of evolution. The fact that the same forms of business may have their own peculiarities in different areas and in different economies is important to consider. Thus, our study showed that despite the emergence of mumpreneurship as a business category in Russia, its essence is significantly different from European practice. Therefore, it would be wrong to use the results of European studies here in Russia. At the same time, taken together, cases from different countries help to compile the data, while their systematization forms trends.

Mumpreneurship studies have begun around the world relatively recently. In this regard, there is an intensive accumulation of evidence about different experiences at the current stage. In prospect, longitudinal research may be extremely interesting due to insight into the stages of business development as children grow older. This observation will help to get better understanding of the mumpreneurship concept: whether it is an independent form of business or an intermediate phase of a woman-owned business.

Our work clearly has some limitations. The analysis has been carried out on a small scale and cannot be generalized to all mumpreneurs of Russian depressed areas. The picture is thus still incomplete. This study is the first step towards enhancing our understanding of mumpreneurship in Russia. However, the evidence from this study revealed certain latent entrepreneurial potential that can be developed and may influence social-economic development of the community. This type of business has its own characteristics. Our work has led us to conclude that it is necessary to form a special regulatory policy for the better use of its potential. In Russia, support to small business development is declared to be one of the priorities of the state policy. In this regard, our findings would seem to have a possibility of practical application. The authors believe that this study also contributes to the theory of entrepreneurship, as well as makes sense to post-Soviet countries that have a common socio-economic past. 


\section{References}

1. C. Brush, A. De Bruin, F. Welter, A Gender-Aware Framework for Women's Entrepreneurship. International Journal of Gender and Entrepreneurship, 1(1), (2009)

2. D. Kelley, S. Singer, M. Herrington, 2015/2016 Global Report from Global Entrepreneurship Monitor (2016)

3. Oxford Dictionary. Retrieved from English Oxford Living Dictionaries: https://en.oxforddictionaries.com/definition/us/mompreneur (Last accessed 03.01.2019)

4. C. Ekinsmyth, Challenging the boundaries of entrepreneurship: The spatialities and practices of UK. Geoforum, 42(1) (2011)

5. S. Shane, E. A. Locke, C. J. Collins, Entrepreneurial motivation (2012)

6. U. Stephan, M. Hart, C.-C. Drews. Understanding Motivations for Entrepreneurship (Birmingham, UK: Enterprise Research Centre and Aston Business School, Aston University 2015)

7. G. Segal, D. Borgia, J. Schoenfeld. The motivation to become an entrepreneur. International Journal of Entrepreneurial Behavior \& Research, 11(1) (2006)

8. J. Hessels, M. van Gelderen, R. Thurik, Entrepreneurial aspirations, motivations, and their drivers. Small Business Economics, 31(3) (2008)

9. A. Carsrud, M. Brannback, Entrepreneurial Motivations: What Do We Still Need to Know? Journal of Small Business Management, 49(1) (2010)

10. K. Richomme-Huet, V. Vial, A. d'Andria, Mumpreneurship: a new concept for an old phenomenon? International Journal of Entrepreneurship and Small Business, 19(2) (2013)

11. C. Ekinsmyth, Mothers' business, work/life and the politics of 'mumpreneurship'. Gender Place and Culture: A Journal of Feminist Geography, 21(10) (2013)

12. C. Ekinsmyth, Managing the business of everyday life: the roles of space and place in "mumpreneurship". International Journal of Entrepreneurial Behavior \& Research, 19(5) (2011)

13. P. Nel, A. Maritz, O. Thongprovati, Motherhood and Entrepreneurship: the Mumpreneur Phenomenon. International Journal of Organizational Innovation, 3 (2010)

14. C. Mason, D. Reuschke, S. Syrett, M. van Ham. Entrepreneurship in Cities: Neighbourhoods, Households and Homes (Cheltenham, UK, Edward Eldar Publishing Limited 2015)

15. H. Ahl, Why Research on Women Entrepreneurs Needs New Directions, Entrepreneurship Theory and Practice, 30(5) (2006)

16. K. Loscocco, A. Smith-Hunter.Women home-based businesss owners: insights from. Women in Management Review, 19(3) (2004)

17. S. Sheikh, S. Yousafzai, Institutional embeddedness of mumpreneurship in the UK: A career narrative. International Diana Conference on Women's Entrepreneurship Research (Wellesley, MA, USA, 2015) 
18. J. Duberley, M. Carrigan. The career identities of 'mumpreneurs': Women's experiences of combining enterprise and motherhood. International Small Business Journal, 31(6) (2012)

19. P. Thompson, D. Jones-Evans, C. Kwong, Women and Home-based Entrepreneurship: Evidence from the United Kingdom. International Small Business Journal, 27(2) (2009)

20. A. d'Andria, Un éclairage sur le processus entrepreneurial des mampreneurs. Étude exploratoire de leur dynamique effectuale. Revue de l'Entrepreneuriat, 13 (2014)

21. A. Mottaeva, MATEC Web of Conferences, 170, 01053 (2018) doi: $10.1051 /$ matecconf $/ 201817001053$

22. D. Boneberger, Mumpreneurs: Motivational factors for Swedish mothers to start their own businesses. (Sweden, Jönköping University, 2015)

23. R. Casteleijn-Osorno, Comparing sense-making of identities of mompreneurs in Malta and Finland (Espoo, Finland, Aalto University, 2014)

24. C. Harris, R. Morrison, M. Ho, K. Lewis, Mumpreneurs: Mothers in the Business of Babies. 22nd Annual Australian and New Zealand Academy of Management Conference (ANZAM), 2-5 December 2008 (Auckland, New Zealand, 2008)

25. C. Gumbo, S. Ditshupo, A Comparative Study of Home-Based versus Out-of Home Mumpreneurship Ventures Challenges in Botswana. International Journal of Advanced Research, 4(6) (2016)

26. N. Patterson, S. Mavin. Women entrepreneurs: jumping the corporate ship or gaining new wings. 30th International Conference of the Institute for Small Business and Entrepreneurship, 7-9 November 2007 (Glasgow, UK, 2007)

27. A. Mottaeva, N. Gritsuk, MATEC Web of Conferences 106, 08083 (2017) DOI: 10.1051/matecconf/201710608083

28. M. A. Bahauovna, M. A. Bahauovna, International Journal of Applied Engineering Research, 10(23), 43446-434499 (2015)

29. J. Larty, E. Hamilton. Structural approaches to narrative analysis in entrepreneurship research. International Small Business Journal, 3(29) (2011)

30. H. Arksey, P. Knight, Interviewing for Social Scientists: An Introductory Resource with Samples. (London: Thousand Oaks, CA: Sage, 1999)

31. F. Herzberg, B. Mausner, B. Snyderman. The Motivation to Work. (New Brunswick (USA) and London (UK): Transaction Publishers 1993)

32. H. D. Lasswell, D. Lerner, I. de Sola. The Comparative Study of Symbols (Stanford, CA: Stanford University Press, 1952) 